\title{
Diagnosis and Treatment of Pityriasis Rubra Pilaris
}

\author{
Alexey KUBANOV ${ }^{1,2}$, Yulia GALLYAMOVA, ${ }^{2, *}$ \\ ${ }^{1}$ State Scientific Center of Dermatovenereology and Cosmetology \\ ${ }^{2}$ Department of Dermatovenereology, Mycology and Cosmetology of Russian Medical Academy of Postgraduate Education \\ Studies, Moscow, Russia \\ *Correspondence: Yulia Gallyamova, E-mail: derma2006@yandex.ru \\ UDK 616.511-07 \\ 616.511:615.262 \\ DE GRUYTER
OPEN
}

\begin{abstract}
The article deals with clinical diagnosis and treatment of pityriasis rubra pilaris (PRP). The authors analyze the diagnostic errors, present literature review, and their own observations. The clinical study included 23 patients with pityriasis rubra pilaris: 18 women and 5 men, average age of $54 \pm 7.2$. The clinical diagnosis of all examined patients was subsequently confirmed by histological analysis of the skin. The primary clinical diagnosis was psoriasis in 15 (65.2\%) patients, 6 (26\%) patients received treatment for toxic exanthema, and only $2(8.8 \%)$ patients were presumptively diagnosed with pityriasis rubra pilaris. In conclusion, pityriasis rubra pilaris was initially misdiagnosed in $91.2 \%$ of patients. Considering the great number of diagnostic errors, we analyzed the main diagnostic and differential diagnostic features of PRP. The most effective of all synthetic retinoids in PRP treatment is acitretin. Although symptomatic improvement in PRP occurs within a month, substantial improvement, even clearing is possible within 4 - 6 months.
\end{abstract}

\section{Key words}

Pityriasis Rubra Pilaris; Diagnosis; Diagnosis, Differential; Diagnostic Errors; Acitretin; Treatment Outcome

$\mathrm{P}$ ityriasis rubra pilaris (PRP) is a heterogeneous group of chronic skin conditions including familial forms, inherited in an autosomal dominant fashion, transplacental transmission, and sporadic acquired forms (1-4).

\section{Introduction}

Pityriasis rubra pilaris was first described by Claudius Tarral in 1828 (5). He noted isolated scaly asperities, round-shaped, in the middle of which a hair breaks through; to the touch a solid roughness is felt $(1-3,5)$.

PRP is a rare condition which accounts for $0.03 \%$ of all skin diseases. The etiology and pathogenesis are still poorly understood, and the opinions of contemporary authors are controversial. The theory of genetic predisposition prevails. PRP affects both males and females equally. The age of disease onset has three peaks: $1^{\text {st }}, 2^{\text {nd }}$ and $6^{\text {th }}$ decades. The course of the disease is chronic, sometimes it lasts for decades and it is not season related (1).
In 1980 Griffiths described 5 clinical subtypes of PRP (6): classic adult type; atypical adult type; classic juvenile type; circumscribed juvenile type, and atypical juvenile type.

In contemporary dermatology it is widely accepted that classic adult type and classic juvenile type have similar clinical features and differ only in the age of onset. Therefore, today PRP is classified into three clinical subtypes: classic type; circumscribed juvenile type, and HIV-associated type (1).

The diagnosis of PRP is difficult, especially in the initial stage, as the typical clinical picture develops slowly. It includes rash, circumscribed follicular keratoses, branny scales with perifollicular orange-red erythema, and palmoplantar keratoderma. Follicular papules are cone-shaped with typical spinulose appearance - "cones of Besnier" $(2,7,8)$. These cones produce a "grater" effect, and the skin may feel rough to touch (Figure 1). In the literature, follicular 


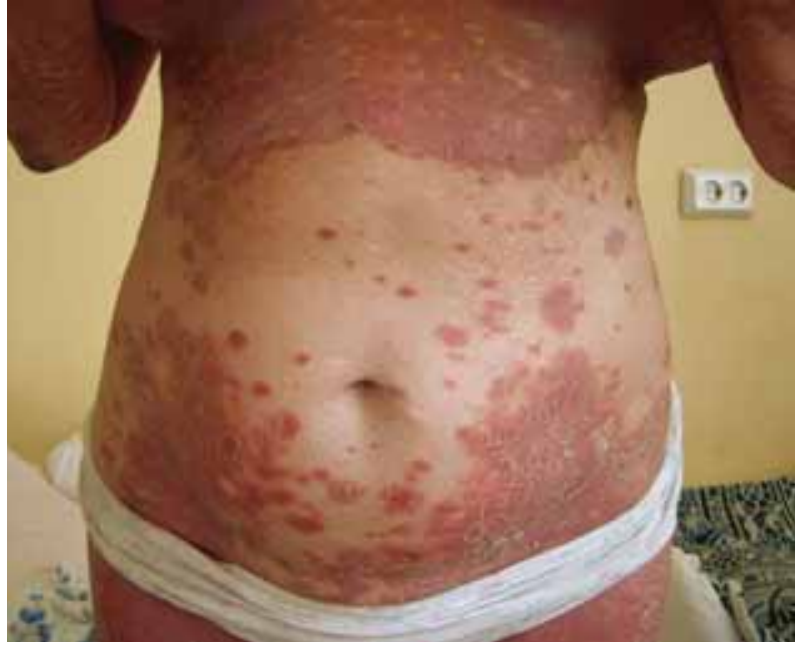

Figure 1. Pityriasis rubra pilaris (PRP)

hyperkeratosis on the dorsal aspects of the I-II finger bones is known as the "symptom of Besnier". The color of eruptions is brick-red or yellowish red, that is typical for PRP. It may have a sudden or gradual onset. PRP usually starts with erythematous patches or with a single erythematous plaque and then

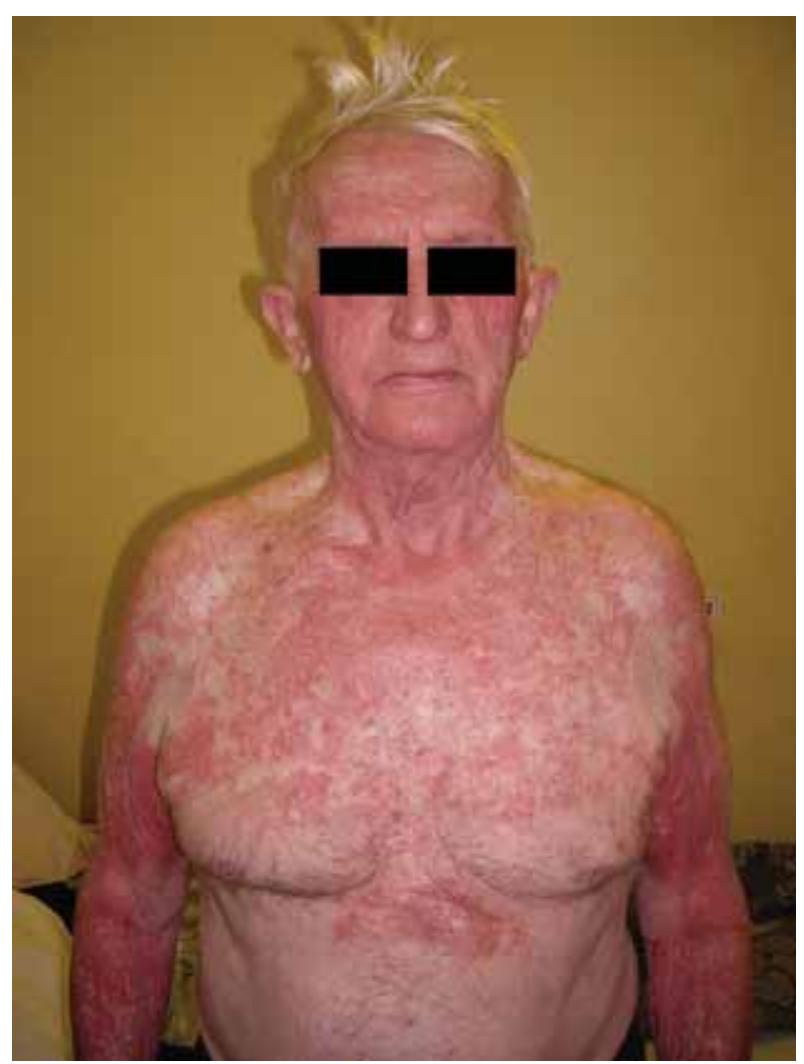

Figure 2. A 72-year-old male with PRP at the onset of disease spreads (Figures 2, 3). The first onset is associated with erythematosquamous lesions on the face and pityriasis capitis (dandruff) on the scalp, which are accompanied by itching of different intensity and may resemble seborrheic dermatitis. Over time the clinical picture changes; the disease spreads and gradually gets features of diffuse erythroderma due to the fusion of erythematosquamous plaques; the hallmark of this condition is the presence of "islands of unaffected skin" within generalized erythroderma (Figures 4, 5). The presence of discoid-shaped islands of unaffected skin is very important for the detection of PRP and sometimes it is one of the most important distinctive features. The islands are usually one centimeter in diameter, and remain scattered over the erythema on any part of the skin. The scaling is heterogeneous: scales on the upper part of the body are small, whereas on the lower part of the body scales are mostly large, lamellar. These clinical features together with follicular hyperkeratosis on the back side of finger bones ("symptom of Besnier") are observed in 50\% of cases. The palmoplantar hyperkeratosis appears

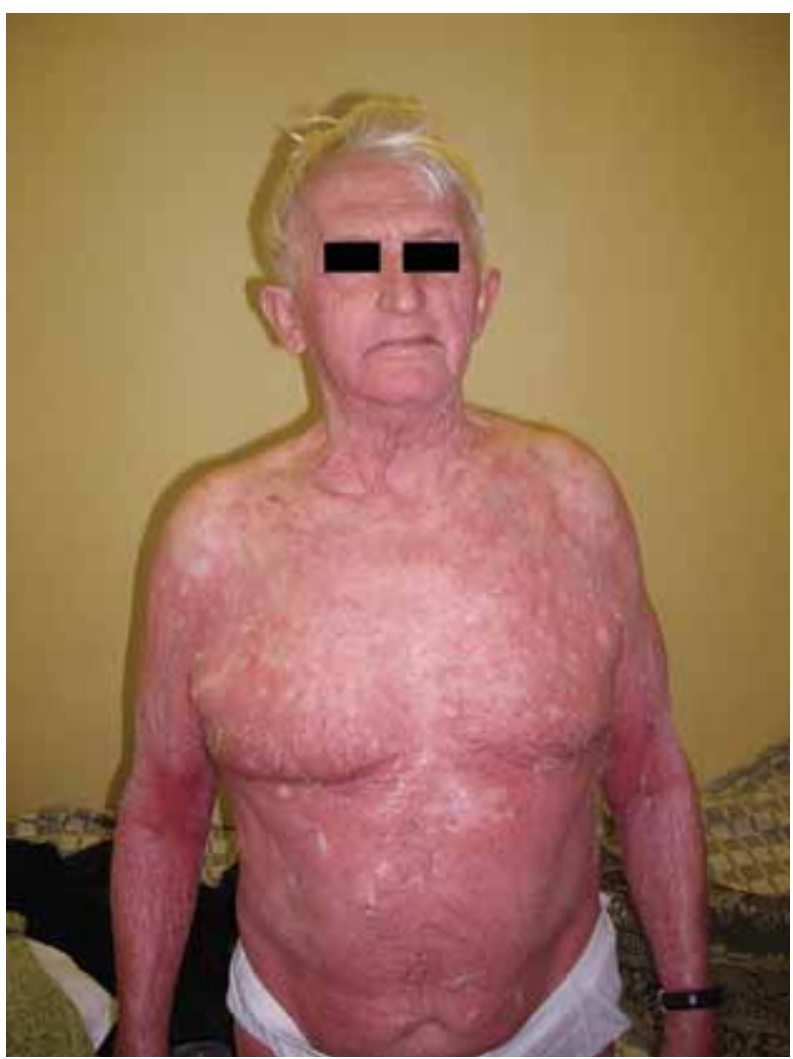

Figure 3. A 72-year-old male with PRP, 2 weeks after the onset of disease 


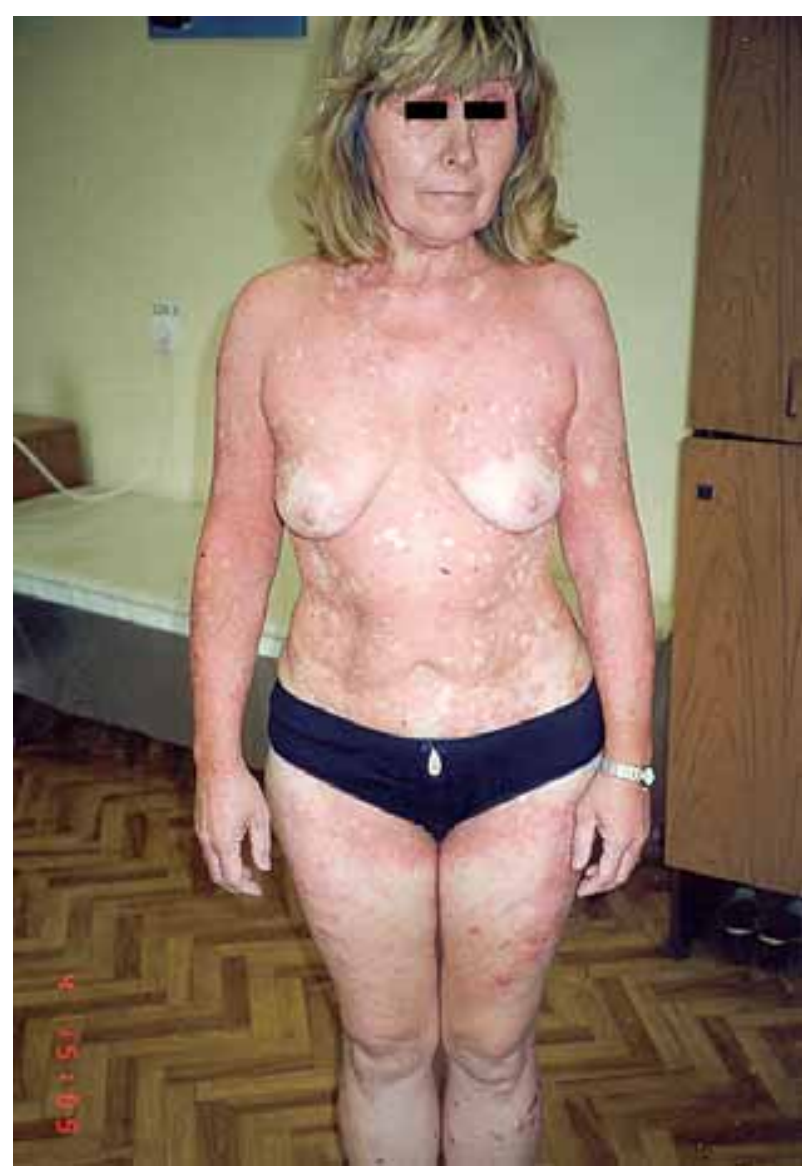

Figure 4. "The islands of unaffected skin" on the background of erythroderma in PRP

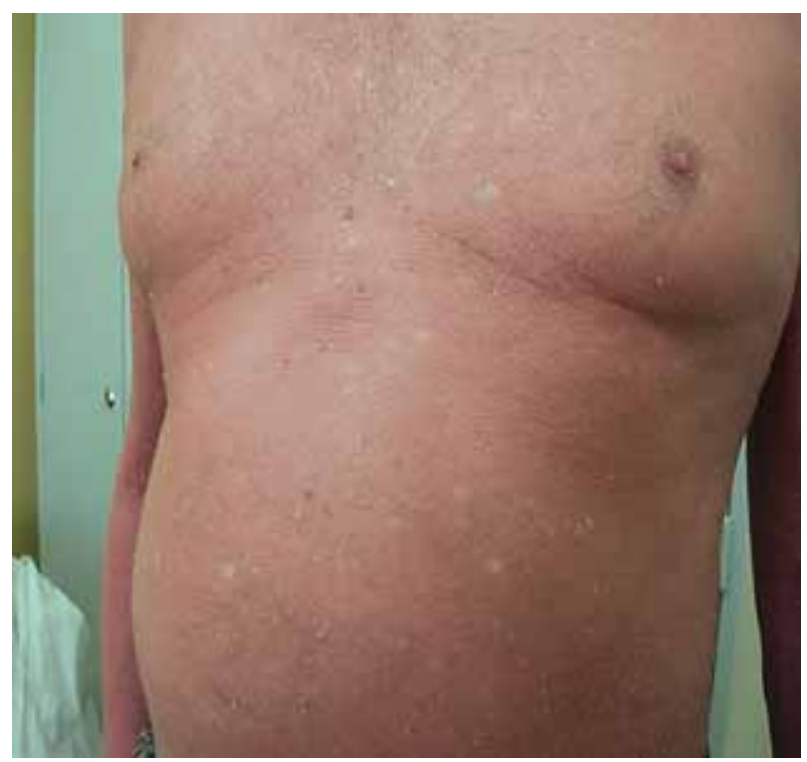

Figure 5. "The islands of unaffected skin" on the background of erythroderma in PRP

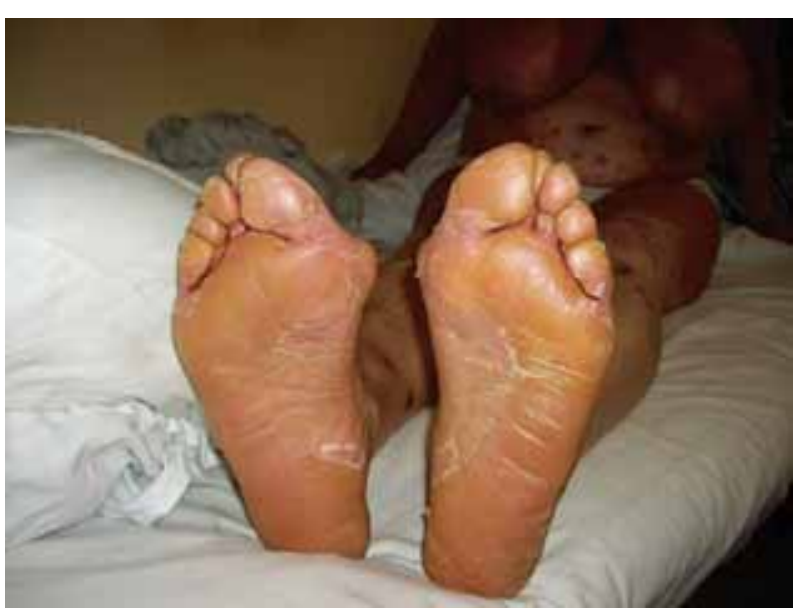

Figure 6a. The patient with PRP: plantar hyperkeratosis

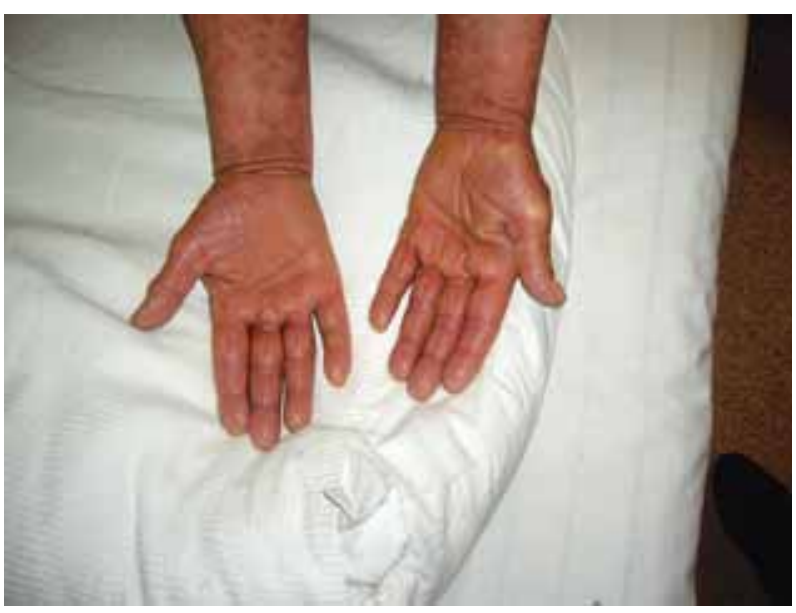

Figure 6b. The patient with PRP: palmar hyperkeratosis

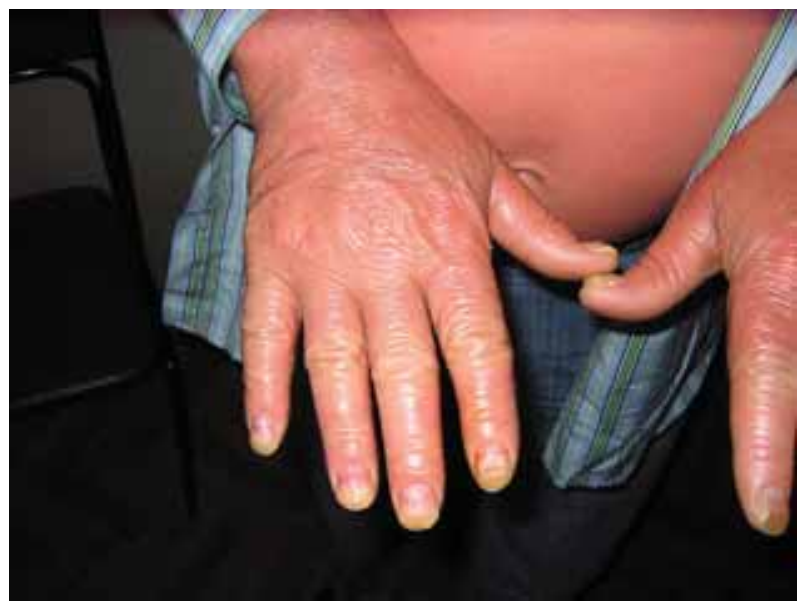

Figure 7. Regrowth of healthy nails in PRP after acitretin therapy $30 \mathrm{mg} /$ aday within 4 months 
simultaneously with the disease onset or later (Figure 6) $(1,2,3,7)$.

Nail plates are frequently affected; they are yellowish in color, and striated with longitudinal or transversal sulci and subungual hyperkeratosis that appears quite often. In some cases onychogryphosis develops.

The diagnosis is based on clinical findings: perifollicular papules with a central keratotic acuminate plug, producing a "grater" effect; perifollicular erythema with a tendency to fusion; "islands of unaffected skin" within generalized erythroderma; brick-red color of the skin; palmoplantar hyperkeratosis; nail alterations; "symptom of Besnier" $(1,4)$.

However, eruptions of PRP and diffuse erythema, in the form of exfoliative dermatitis, very often resemble psoriasis (4).

\section{Case series}

The clinical study included 23 patients with PRP: 18 women and 5 men, average age of $54 \pm 7.2$. The clinical diagnosis of all examined patients was confirmed by histological analysis of the skin.

The primary diagnosis was psoriasis in 15 (65.2\%) patients, $6(26 \%)$ patients received treatment for toxic exanthema, and only $2(8.8 \%)$ patients were presumptively diagnosed with PRP. Considering the great number of diagnostic errors, we analyzed the main diagnostic and differential diagnostic features of PRP.

Firstly, the general condition was not disturbed in any of the patients with PRP and it remained the same, even in patients with diffuse lesions (Figures 1 5), which was in contrast with patients with psoriatic erythroderma, who complained about prodromal symptoms, subfebrile fever and fatigue. The pertinent complaints of PRP patients included the skin lesions, feeling of tightness and dryness.

In differential diagnosis of PRP, special attention was paid to typical signs of the disease - "islands of unaffected skin" (Figures 1, 5). All supervised patients had this feature. It is easy to distinguish this feature from areas of uninvolved skin in psoriatic erythroderma if we bear in mind that "islands of unaffected skin" in PRP do not exceed $1.5 \mathrm{~cm}$ in diameter (Figure 5), have well defined clear round ring-shaped borders, and are located within generalized erythroderma (Figure 5). In the diagnosis of PRP, the first presentation is papule with a hair in its center. However, follicular form of psoriasis should not be forgotten, when patients also present with pink papules with a hair in the center. In such cases, it is quite complicated to distinguish the two diseases, but typical psoriatic plaques affect specific locations: scalp, extensor surface of the limbs. A dynamic supervision of patients allows correct diagnosis. Psoriatic papules always have an inclination to peripheral growth and fusion due to skin infiltration, in contrast to PRP where diffuse erythroderma is formed due to an ongoing erythematosquamous process. The absence of infiltration, lichenification, and profuse lamellar scaling, essential for psoriasis, counted in favor of PRP.

In 7 patients $(30.4 \%)$ the skin color was carrotorange and $16(69.6 \%)$ had a brick-red skin tone. However, 19 (82.6\%) patients had palmoplantar hyperkeratosis, with yellow-orange color (Figures $6 a$ and 6 b). Though $18(78.2 \%)$ patients had nail disorders, we would like to note that this feature most likely depends on remoteness of the disease, since the rate of the nail plate growth is much slower than the pathologic process.

Our observations have confirmed that: disease duration in patients with nail disorders varied from 4 to 10 months. Nail plate changes were characterized by subungual hyperkeratosis, discoloration, and longitudinal or transverse striations (Figure 7). However, none of the patients had onycholysis, typical for psoriasis.

After the diagnosis was established and hystopathologically confirmed, acitretin was initiated at a dose of $0.5-0.7 \mathrm{mg} / \mathrm{kg} /$ day. Therapy analysis of PRP patients revealed that the most frequent sideeffects were present in all 23 patients including dry lips, cheilitis (particularly angular cheilitis), skin dryness with skin exfoliation and xerostomia $(n=23$; $100 \%)$; alopecia $(\mathrm{n}=12 ; 52 \%)$; thirst and dry mouth $(\mathrm{n}=5 ; 21.7 \%)$; less common were intolerance to contact lenses in 3 patients (13\%), conjunctivitis and stomatitis, each in 2 patients $(8.6 \%)$, nosebleed, rhinitis and change in taste sense, each in 1 patient $(4.3 \%)$.

The medium duration of treatment was 9 months, whereas the nail condition improved faster than the skin condition (Figure 7). 


\section{Disscusion}

As it has already been mentioned above, PRP was initially misdiagnosed in $91.2 \%$ of patients. Most of them were treated with antihistamines. In 15 patients (65.2\%) prolonged therapy with systemic steroids was commenced, without any improvement. This fact confirms once more that PRP is resistant to usual therapy.

Summarizing the aforesaid, we can outline the main differential and diagnostic features which distinguish pityriasis rubra pilaris from psoriasis:

- the general health of PRP patients remained good in contrast to psoriatic, even if their skin was diffusely affected;

- "islands of unaffected skin" was a typical feature;

- the primary lesion presents with plaques and follicular involvement;

- brick-red or carrot-orange color of the skin;

- the absence of infiltration, lichenification, and profuse lamellar scaling which are essential for psoriasis;

- the absence of onycholysis which is typical for psoriasis;

- palmoplantar hyperkeratosis, yellow-orange in color, without infiltration;

- ineffective, antihistaminic and hormonal treatment.

Today, retinoids appear to affect the processes of keratinization. In 1930, Moore first synthesized retinol from carotenoid and began studying its systemic action (9). The most effective of all synthetic retinoids in PRP treatment is acitretin at a dose of $1.0-1.5 \mathrm{mg} / \mathrm{kg} /$ day. The average daily dose varies between 25 - $50 \mathrm{mg}$ per day $(1-3,7,10)$. However, one should not count on fast clinical effects in the treatment of PRP, especially in adults. Our opinion coincides with the opinion of other authors that symptomatic improvement in PRP occurs within a month, but substantial improvement, even clearing is possible within 4 - 6 months $(1-3,7,10)$. According to some data the average length of treatment is about 4 years (1). In our PRP patients the medium duration of treatment was 9 months, and the nail condition improved faster than the skin condition (Figure 7).

Acitretin is known to have strong teratogenic effects. The risk for birth defects is very high, especially if acitretin is taken before or during pregnancy, no matter for how long or at what dosage. Acitretin is a US FDA Pregnancy Category X medication that should not be administered during pregnancy and 3 years after discontinuation (11).

It is well known that the majority of patients receiving acitretin have side-effects. These sideeffects usually disappear after dose reduction or drug withdrawal $(1,10,12)$. It is significant that aggravation of symptoms is usually observed at the beginning of the disease.

Liver function tests need to be performed before the initiation of acitretin, every $1-2$ weeks within the first month, and then every 3 months during maintenance therapy. During treatment with high doses of acitretin, reversible triglyceride and cholesterol elevation is possible, especially in patients with lipid disorders, diabetes, obesity, or alcohol abuse $(12,13)$. If hepatic function fails to return to normal, acitretin should be widthrown. In such cases, it is advisable to continue monitoring the hepatic function for at least three months. In diabetic patients retinoids can alter glucose tolerance, therefore in the early stages of treatment blood sugar levels should be checked more often than usual. There are a few articles about the appearance of diffuse oedema during acitretin therapy (14).

According to some authors, methotrexate (MTX) may be an alternative therapy at a dose of $15-25$ $\mathrm{mg} /$ week. In a recent report it has been observed that adding MTX (5-30 mg/week) to oral retinoids during 16 weeks increased the positive therapeutic response by more than $50 \%$ in 8 of 11 patients, but the combination may lead to increased hepatotoxicity $(1,15)$.

Although regarded only as adjuvant, topical treatment during retinoid therapy significantly improves the general state of patients and their quality of life. Moisturizing creams, ointments with salicylic acid $2-5 \%$, urea 10\%, malic acid $1-20 \%$ should be prescribed in the treatment of palmoplantar hyperkeratosis.

The use of ultraviolet irradiation is inadvisable in PRP patients $(1,16)$. According to our observations, all examined patients had acute exacerbation after ultraviolet irradiation or insolation. In severe cases, antagonists of tumor necrosis factor-alpha are an effective treatment option (17) . 


\section{Conclusion}

Recent scientific discoveries have greatly improved the understanding of clinical and genetic polymorphism of hereditary skin diseases; knowledge in pathomorphology and immunomorphology has significantly advanced and in turn increased the possibility of accurate diagnosis of PRP. The use of synthetic retinoids has increased treatment efficiency in these patients. However, the treatment of PRP is long and challenging due to side-effects, contraindications in elderly people and in patients with a disease burden.

\section{Abbreviations}

PRP - pityriasis rubra pilaris

HIV - human immunodeficiecy virus

US FDA - United States Food and Druf Agency

MTX - methotrexate

\section{References}

1. Katsambas A, Lotti T, editors. European handbook of dermatological treatments. $2^{\text {nd }}$ ed. Berlin, Heidelberg: Springer; 2003.

2. Pincus DJ. Pityriasis rubra pilaris: a clinical review. Dermatol Nurs 2005;17(6):448-51.

3. Naciri Bennani B, Cheikh Rouhou H, Waton J, Cuny JF, Bassegoda G, Trechot P, et al. Pityriasis rubra pilaris after vaccination. Ann Dermatol Venereol 2011;138(11):753-6.

4. Judge MR, McLean WHI, Munro CS. Disorders of keratinization. In: Burns T, Breathnach S, Cox N, Griffiths C, editors. Rook's textbook of dermatology. $8^{\text {th }}$ ed. Oxford:
Blackwell Publishing Ltd; 2010. p. 19.1-19.122.

5. Tarral C. General psoriasis. Desquamation from the parts covered with hair. In: Rayer P. A theoretical and practical treatise on the diseases of the skin. 2nd edn. London: Baillière; 1835. p. 648-9.

6. Griffiths WA. Pityriasis rubra pilaris. Clin Exp Dermatol 1980;5:105-12.

7. Pitman J, Muekusch G. Pityriasis rubra pilaris. Dermatol Nurs 2005;17(4):302.

8. Besnier E. Observations pour servir a l'histoire clinique du pityriasis rubra pilaire. Ann Dermatol Syphiligr (Paris) 1889; 10:253-87.

9. Moore T. Vitamin A and carotene: the absence of the liver oil vitamin A from carotene. VI. The conversion of carotene to vitamin A in vivo. Biochem J 1930;24(3):692-702.

10. Lynde CW, Kraft JN, Lyndec B. Acitretin revisited. Skin Therapy Lett 2011;16(3):1-4.

11. Carretero G, Rinera M, Belinchon I, Carrascosa JM, Puig L, Ferrandiz C, et al. Guidelines for the use of acitretin in psoriasis. Psoriasis Group of the Spanish Academy of Dermatology and Venereology. Actas Dermosifiliogr 2013;104(7):598-616.

12. Pearce DJ, Klinger S, Ziel KK, Murad EJ, Rowell R, Feldman SR. Low-dose acitretin is associated with fewer adverse events than high-dose acitretin in the treatment of psoriasis. Arch Dermatol 2006;142:1000-4.

13. Berbis P. Acitretine. Ann Dermatol Venereol 2001;128(67):737-45.

14. Estival JL, Dupin M, Kanitakis J, Combemale P. Capillary leak syndrome induced by acitretin. $\mathrm{Br} \mathrm{J}$ Dermatol 2004;150(1):150-2.

15. Holliday AC, Megan NM, Berlingeri-Ramos A. Methotrexate: role of treatment in skin disease. Skin Therapy Lett 2013;18(3):4-9.

16. Osório F, Magina S. Phototherapy and photopheresis. Expert Rev Dermatol 2011;6(6):613-23.

17. Gemmeke A, Schönlebe J, Koch A, Wollina U. Pityriasis rubra pilaris a retrospective single center analysis over eight years. J Dtsch Dermatol Ges 2010;8(6):439-44.

\section{Dijagnoza i lečenje pitirijaze rubra pilaris - prikaz serije slučajeva}

\section{Sažetak}

Uvod i cilj. U radu autori na osnovu podataka iz literature i sopstvenog iskustva, analiziraju klinički zasnovane kriterijume za postavljanje dijagnoze i lečenje pitirijaze rubra pilaris (PRP), ističu moguće greške, odnosno izazove u postavljanju dijagnoze ove heterogene grupe dermatoza.

Serija slučajeva. U radu su analizirane 23 osobe kod kojih je postavljena klinička dijagnoza. Ukupno je bilo 18 žena i 5 muškaraca, prosečna starost iznosila je $54 \pm$ 7,2 godine. Klinička dijagnoza je kod svakog pacijenta potvrđena patohistološkom analizom isečka uzetog sa promenjene kože. Prvobitno je postavljena dijagnoza psorijaze kod 15 (65,2\%) pacijenata, $6(26 \%)$ je lečeno pod dijagnozom toksičnog egzantema, a samo je kod $2(8,8 \%)$ postavljena dijagnoza pitirijaze rubre pilaris. U 91,2\% slučaja, postavljena je pogrešna dijagnoza.

Diskusija. Uzimajući u obzir brojne izazove i učinjene greške, analizirani su glavni dijagnostički i diferencijalno-dijagnostički kriterijumi, što je autorima omogućilo da razlikuju pitirijazu rubra 
pilaris od psorijaze:

- Dobro opšte stanje kod pacijenata sa PRP koje za razliku od obolelih od psorijaze ostaje nepromenjeno čak iako je koža difuzno zahvaćena eritrodermijom;

- Tipično za PRP je zaostajanje ostrvaca klinički nepromenjene kože;

- Primarnu leziju PRP predstavlja papula iz čijeg centra izrasta dlaka;

- Oranž boja kože u PRP poredi se sa bojom cigle, odnosno mrkve;

- Odsustvo infiltrata, lihenifikacije, velikih lamelarnih skvama u PRP, koji su svi ključni za postavljanje dijagnoze psorijaze;

- Odsustvo u PRP oniholize, koja je tipična za psorijazu;

- Palmoplantarna hiperkeratoza u PRP pokazuje karakterističnu žućkastooranž boju i odsustvo infiltracije;

- Hormonska terapija u PRP, u prvom redu kortikosteroidima ostaje bez željenog efekta.

Analizom postignutih terapijskih rezultata, u grupi sintetskih retinoida najveću efikasnost ispoljio je acitretin. Iako je simptomatsko poboljšanje nastupalo unutar prvih mesec dana, do značajnijeg poboljšanja ili izlečenja dolazilo je tek nakon 4,6 4-6 meseci.

Zaključak. Za postavanje dijagnoze pitirijaze rubra pilaris značajnu ulogu ima dobro poznavanje kliničkih osobina oboljenja, dok za postizanje punog terapijskog efekta retinoidima treba ostaviti duže vreme - čak i više meseci.

\section{Ključne reči}

Pityriasis Rubra Pilaris; Dijagnoza; Diferencijalna dijagnoza; Dijagnostičke greške; Acitretin; Ishod terapije 